Gadjah Mada International Journal of Business

January 2002, Vol. 4, No. 1, pp. 1-16

\title{
MANAGEMENT STYLES IN A GLOBAL MARKET ECONOMY
}

\section{Luchien Karsten}

Globalization is the intensification of the spatial organization of social relations and transactions, which put distant localities and local activities at a level of worldwide range, consequence and significance. These activities cluster into new reality like a globally operating market system and a globally developing technoscience. The question is to what extent a global civil society will come about too. At the level of internationally operating firms management styles will have to be developed to enhance the understanding of cultural heterogeneity within this global civil society. Cultural complexity will increase due to the intensification of interactions and transactions. Within and between internationally operating firms. Communicative rationality in terms of dialogue and conversations should be reinforced to deal adequately with this complexity. Coтmunicative rationality perceives language not only as a mere representation of an objective reality but also as a human practice in a social context. Firms operating as communities of practice will enhance through proper management styles the reciprocal understanding we need in a world economy.

Keywords: dialogue; language; leadership; management styles; management systems; speech act theory; visible hand 


\section{Introduction}

Fifty years ago a well-known Dutch historian, Jan Romein, visited the Gadjah Mada University and gave a lecture (4 Feb. 1952) on the unification of the world and the voice of Asia. He was impressed by the political and economic development of the Asian societies and thus, in 1956, he published a book reflecting his fascination for these developments. ${ }^{1}$ In his second lecture, he depicted the peculiar European development, which was initiated during the 16th century, as a deviation from a general human pattern of behavior. He did not clearly describe what he meant, but he seemed to refer to an original Arcadian condition where the human race still lived in harmony with nature. Romein was convinced that Europe inherited certain traditions and organizational capabilities from the Greeks and the Romans to build a society focused on striving for profit. Instead of enjoying one's life at the present, individuals had to postpone pleasures or benefits from hard work to a later moment. This statement beard reminiscences to the well-known Weber thesis stating that Protestantism, more in particular Calvinism, had been one of the essential sources for the development of industrial capitalism. Romein believed that Asia stood on the brink of awakening and it might somehow copy the western world, deviating from the general human pattern of behavior too. "The process of westernization of Asia has just begun and could only begin now after the liberation from the dominion by the West" (Romein 1952: 145).

During the 1950s, it was a commonly shared view that the industrialization of nations should take place according to the ways the West had developed. A process of imitation and adaptation was seen as a secure way to promote economic development, and the knowledge required was to be transferred to the rest of the world. Therefore, in this paper, I wish to question this perspective, for I do not agree that there is one socioeconomic model according to which economic development will be guaranteed, even if there is one common global market. Furthermore, there is no one universal business model, which will support such a view. Instead, we have to respect that there are different systems of management, which exist with a variety of (multi) cultural traditions. Within these systems, different management styles can be pursued based upon the specific business context firms are operating. Does this imply that there are no common features amongst human kind for us to be able to understand these varieties in management styles? I believe that we are all endowed to understand and respect each other, especially in today's multicultural societies.

\section{Globalization of the Markets}

Any society that has not closed its borders or protected itself from outsiders, but showed willingness to cross borders, demonstrates an international focus. As such, the phenomenon is not of a recent date, but an integral part of many societies. According to Frank (1998), the economic center of the world until the year 1800 was located in Asia due to the fact that trade within the Indian Ocean was larger and more important than the trade between Asia and Europe or the United States and Europe.

\footnotetext{
1 "De eeuw van Azië: opkomst, ontwikkeling en overwinning van het modern-aziatisch nationalisme," Leiden 1956.
} 
The first society that experienced its international orientation in terms of covering the globe, however, was the Spanish Kingdom of Philip II. After the annexation of Portugal and his overseas empire, in 1580, Philip II became the ruler of the first empire in history where the sun never set. "Although its core —and its king - remained in Europe, issues concerning Africa, Asia, and America regularly flowed across Philip's desk and required countless decisions" (Parker 1998: 3). Philip's purpose was to conquer the world by military force, reap the fruits of gold and spices, and impose the catholic religion on all its subjects. Throughout history we have seen several empires, which strove for the same purpose, but failed. The single phenomenon that did not disappear, however, was the market. Since the $16^{\text {th }}$ century, we have seen the increasing importance of global markets. The remarkable principle of allocation with its price mechanism finally created markets as a spin-off from military societies that strove for dominion.

Adam Smith in his famous 'Wealth of Nations' (1776) defended the proper functioning of the market mechanism. In his chapter about international trade, he argued strongly against restrictions on imports, and the merchants and manufactures who supported such restrictions. Domestic monopolies are advantageous for specific industries, but not for the "general industry of the society" (Smith 1976: Book IV).

In a free market, merchants will support domestic industries in the interest of their own security. Any merchant will thereby promote the interest of the society: "he is in this, as in many other cases, led by an invisible hand to promote an end which was no part of his intentions" (Smith 1976: 462; 471). Smith was not precisely clear on what he meant with the concept of the invisible hand. According to Rothschild (2001), Smith used about a dozen different interpretations of the invisible hand, but in her view, the overarching topic for Smith was that the invisible hand requires, "both good institutions and norms, whereby individuals pursue their interests within the rules of well-defined games and not by seeking to influence institutions and rules" (Rothschild 2001; 127).

Since the $18^{\text {th }}$ century, we have seen a continuous struggle between the development of free market and concomitant institutions to prevent the ideology of market to downplay the interest of society. We can nevertheless see that the process of internationalization continued.

After the Second World War the global market concept expanded further, but was dominated by two superpowers, who divided the world into two hegemonic blocks, the first and second world. Those not participating in either were reduced to being categorized as the third world countries. With the disappearance of the Iron Curtain in 1989, the cold war period ended and countries started to trade with each other, which prior to 1990 had been impossible. The command/control era changed into one of command/connect. Every nation willing to participate can join the world economy. Due to the growing influence of multinationals, the process of internationalization turned step by step into globalization, which is nothing more than the "intensification of economic, political, social, and cultural relations across borders" (Braithwaite and Drahos 2000: 8). Globalization, therefore, can be seen as the achievement of a market-orientedness i.e. where the sun never sets. 


\section{Globalization of Firms}

To operate in these international markets and to develop trade, West European countries started to develop new forms of economic organizations. One of these successful trading companies was the United East India Company (Verenigde OostIndische Compagnie - VOC). The VOC was set up in 1602 and the $400^{\text {th }}$ anniversary will largely be commemorated in 2002. The VOC was supported by the Dutch government i.e. States General. The States General conferred upon the VOC "the delegated, sovereign rights to maintain troops and garrisons, fit out warships, impose governors upon Asian populations, and conduct diplomacy with eastern potentates, as well as sign treaties and make alliances" (Israel 1995: 322). The doubleedged sword of military and economic interests made the functioning of the VOC a complicated matter.

The success of European business organizations in overseas commerce between the $16^{\text {th }}$ and $19^{\text {th }}$ centuries has nevertheless largely been due to a remarkable combination of long-distance trade and colonization. Europeans created new forms of partnership and joint stock companies as a result. "These forms did institutionalize a new degree of separation between companies and its owners, and in doing so facilitated unified management of trading voyages and cargo too big for a single investor (Pomeranz 2000: 171). These trading companies were firms that specialized territorially and aimed to exclude everyone else from their geographic niche rather than specializing in a particular range of products or services across many places" (Pomeranz 2000: 192).

What these firms failed to do was to develop a body of knowledge from which managers could learn how to coordinate and control these large-scale organizations. It is generally believed that management knowledge rooted in American soil and was cultivated into organization theory. The essence of organization theory lies in the classification of the relationships between organized structures and processes, and contracts and environments.

The American business historian, A.D. Chandler, argues that the practice of management emerged among American engineers and managers in the railways and the mechanical industries around 18801900. He explains this sudden appearance of management practice by referring to the introduction of large size companies in these fields, which forced businessmen to develop specific management approaches. As a consequence:

- Owners became separated from managers.

- Leading firms established large managerial bureaucracies to coordinate a wide variety of activities and transactions.

- Large-scale production became integrated with mass marketing policies.

- Competition became driven by economies of scale and scope.

Engineers and managers began to mobilize their professional interests by setting up professional associations, professional journals and professional courses at American colleges and universities. "Such societies, journals, and courses appeared first for the functional middle manager in finance, marketing and production, and then for general top managers" (Chandler 1977: 464). Such professional institutions hardly existed in the United States in 1900, but began to flourish by 1920. "Even then they were still uniquely American and did not appear in any strength in other economies until after World War II" (Chan- 
dler 1977: 468). A growing professionalism gave the corporate managers a sense of self-identification.

In Chandler's view, management became a functional response to the new demands as a consequence of the development of mass markets and new technologies. He saw "the appearance of managerial capitalism as an economic phenomenon" and the US as the seedbed for managerial capitalism due to the size and the nature of its domestic market (Chandler 1977: 498).

What the Chief Executive Officers (CEOs) of these large-scale American firms created was a visible hand. Instead of waiting to see how markets respond to their products, they began to influence and even rule the markets.

\section{Visible Hand}

In the 1960s and 1970s, it was generally believed that there was an "industrial logic" in the development of societies, which gave the professional managers hegemony and changed the old fashioned ways of running industry and society (Badham 1986). Management was seen as a hierarchy of functions occupied by entrepreneurs, managers, administrators, engineers and professional specialists who hold the top positions in enterprises. It was believed that management was crucial to the success of business (Kerr 1960). It was the task of political leaders to facilitate market development through the provision of the proper institutions, rules and the development of industrial-relations systems, as well as the propagation of the right management expertise (Kerr 1960). Kerr believed that, "the general direction of management development in all advanced industrial societies is the same" (Kerr 1960: 121).
Scientific discovery, technological innovation, and economic progress constitute the major force for development. It is also believed that the management knowledge developed in the US constituted the basis for the promotion of the internationalization offirms. Large-scale, mass-producing enterprises with a decentralized international focus became the major units of the American business model, which was initially transferred to Europe. The consultancy firm McKinsey and Co. 'sold' decentralization to its European clients to strengthen their international development. "In Britain, where McKinsey had the greatest impact in persuading companies to decentralize, 72 out of the 100 largest businesses adopted the multidivisional structure by 1970 " (McKenna 1977: 228).

However, since the 1970 s, the dominations of the American business model as the universally applicable approach lost its spell even though the 'industrialists' believed that the 'industrial logic' forced other nations to adopt this model as the most advanced approach to which all largescale firms would converge. Companies operating in the global market became increasingly faced with 'cultural' problems. It turned out to be complicated to deal with the institutional context within which these firms were operating. Integrating many national value systems into a competitive organizational culture was still largely ignored (Segalla et al. 2000). Several cross-cultural perspectives on management appeared, focusing on noticeable differences refuting the belief that management systems converge along with the process of modernization.

Three different perspectives contested the negligence for the environment (institutions, rules, norms, values, cultures) within which organizations are operating: 
(a) The US centered new institutionalists

(b) The European societal effects

(c) The business system theorists

\section{The US Centered New Institutionalists}

The major contribution of the institutional school is the emphasis on the environment. It details for specific organizations and their recent history, "the close interaction of organizations and their environment." Organizations are seen as "constantly adapting and improvising to keep afloat and to find goals and values that are consistent with their basic dependencies, sources of financial support, legitimacy, personnel and technologies" (Perrow 1986: 166). According to the institutional school, organizations respond to pressures in their environment to conform the accepted ways of doing business so that they will appear legitimate to investors, customers, employees, etc. with whom they have relationships. Perrow concludes, however, that this approach has failed in perceiving society as adaptive to organizations.

The neo-institutionalists doubted the presence of clear-cut goals, which defined organizations. According to this new approach, organizations do not have identities. The focus, therefore, switched to the problem of how organizations construct their identity in order to legitimate themselves in their relevant environments. Neoinstitutionalism focuses much more on the process of spreading organizational ideas. A main line of argument is that isomorphic forces in the environment influence the formal aspects of organizations through coercive, normative or mimetic processes (Powell and DiMaggio 1991). This perspective has been used to understand the process of diffusion of management concepts. The attention was drawn to the existence of organizational fields and the mechanisms through which managers obtain information to manage and control, rather than to focus on the nature of the socio-economic environments themselves. Neo-institutionalism, however, still embraces the conviction that there is a tendency of convergence although they explain this no longer in terms of socioeconomic forces, but cultural ones. Nevertheless, there is conviction that firms operating within organizational fields reflect processes of standardization in terms of organizational forms and coordination across organizational fields. The long-term result could be a homogenization across organizational fields. The neo-institutionalists are convinced that the same kind of management concepts will be diffused and adopted in the most developed parts of the world.

\section{The European Societal Effects}

The European societal effects school aims to show how the capacities of firms relate to the organization and interaction of occupational groups that constitute the firm. The capabilities or competence of these productive agents are socially produced and formed through socialization processes in different fields in society. Through international comparisons this approach strives to indicate similarities and differences (Maurice and Sorge 2000). It places emphasis on: "(a) the varied ways in which social groups are constituted inside and outside organizations; and (b) their continuous competition for control of resources (Whitley 1999: 12-13)." The societal approach tries to show how different societal institutions and agencies generate different kinds of economic actors pursuing different strategic approaches.

Due to the divergent educational systems for example, elitist in France and egalitarian in Germany, French and Ger- 
man managers differ in their power bases. The French educational system promotes values such as, authoritarianism and respect, and students of grandes écoles are socialized with the idea of a 'natural' distance between top and bottom. In Germany only 16 per cent -in contrast to 46 per cent in France- of the top managers in 1982 had university degrees, but 42 per cent of the middle managers in Germany have university degrees compared to only 20 per cent in France (Maurice et al. 1982: 186). This leads to different leadership styles.

\section{The Business System Theorists}

The business system theorists do not believe in the march to industrialism, but admit that the capitalist sphere is of fundamental importance in structuring social relations. There is a more diversified development within capitalism and the Fordist system of mass production for example, cannot be the predominant production system (Albert 1991; Whitley 1999). This approach is critical to the assumption that one organizational form and management style is inherently superior in all kinds of contexts. Their key argument is that a great variety of economic institutions and organizations are equally viable and that different kinds of management systems and styles may be developed and survive as functional equivalents (Calori and de Woot 1994).

Even though the three aforementioned approaches differ in their analyses, they share a common concern about the processes of divergence within and amongst organizations. Although certain management concepts and policies can be transferred from one country to another and from a firm in one nation to firms in other nations, business practices still manifest a high degree of heterogeneity and diver- sity. Furthermore, institutional and cultural differences will have a very large impact on the constitution of this diversity, and studies have to be undertaken aggressively in order to understand this heterogeneity.

\section{Leadership Approaches}

Cross-cultural research in the organizational science matured during the 1980s. Major studies by Hofstede (1980), Trompenaars and Hampden-Turner(1998) and others contributed substantially to this process. It is now conventional wisdom that search for universal characteristics is unrealistic and the meaning of cultural phenomena is context-dependent. Hofstede (1983) underlined that management approaches will never fully converge and argued nationality influences management for three reasons:

- Nations are historically rooted political entities with their own institutions and legal, educational and labor market systems.

- Informal organizations are usually culturally based.

- Psychological factors and the way of thinking are influenced by national cultural factors, formed by early family relations and educational systems, which differ from country to country.

Cross-cultural studies focused initially on differences between nations and their specific national cultures to deduce specific management behaviors. The cultural focus led to studies in which the unique qualities of the leader seemed to create an organizational culture. Schein (1985) warned that the unique and essential function of leadership seemed to consist in the manipulation of the organizational culture. Transformational leaders had to change organizational cultures as a 
prerequisite for radical strategic change. Leadership became a kind of value engineering. This vision fits neatly with the new leadership approach Bryman (1996) has identified. Reviewing the prevalent literature about leadership, he draws the conclusion that it is difficult these days to differentiate between the leader and manager for both are seen as actors who make decisions and give directions to organizations. Leadership is then perceived as the process of influencing the activities of an organized group in its efforts toward goal setting and social achievement. Bryman nevertheless identified four different approaches, which since the 1950's have been developed - the trait approach, the style approach, the contingency approach, and the leadership approach.

The trait approach seeks to determine the personal qualities and characteristics of leaders. This orientation became very popular in the 1950s and entails a belief that leaders are born rather than made. Researchers have examined a host of different traits such as, physical features, abilities, and personality characteristics. This research, however, has not been able to identify the relationship between traits and successful leadership. Nevertheless the approach was revived in the eighties due to the interest for entrepreneurship. It became clear, however, that the trait-analysis is not sufficient to understand the qualities of a good leader or entrepreneur.

The style approach became popular during 1960s, placing emphasis on the behavior of leaders. Since the behavior of the leader is not fixed but capable of being changed, this approach focused on the training of leaders instead of selecting them. Training programs should make (future) leaders aware that they have to be concerned about their subordinates as hu- man beings and thus, they should be responsive to them. Leadership qualities were studied by analyzing what subordinates expected from them. Employee and task orientation were studied to improve the proper behavior of leaders. Within this approach, research is being undertaken by differentiating, for example, six different leadership styles: coercive, authoritative, affiliated, democratic, pace-setting and coaching and analyzing in which situation it is appropriate to apply a specific style (Bakhtari 1995).

The third approach was introduced during the 1970s when it was discovered that identifying leadership qualities of an individual actor was not sufficient for a company to achieve its goals. Initiatives leaders was taking as well as the outcomes of their actions turned out to be situationally contingent. Proponents of the contingency approach placed situational factors towards the center of any understanding of leadership. They were seeking to specify the situational variables, which will moderate the effectiveness of a leader. Contingent or situational studies of leadership showed that effective leaders used an appropriate style to deal with managerial issues in specific situations. This approach parallels the drift away from universalistic theories of organizations from the 1960s and 1970s, and the gradual option of a more particularistic framework that reflects a way of thinking which Lawrence and Lorsch (1967) assumed as "it all depends." Dichotomies such as, task oriented versus relational oriented, democratic versus autocratic, and employee related versus job centered, became popular schemes to identify the position a leader could take depending upon how favorable a specific situation was for him/her.

While identifying three categories (i.e. interpersonal, information oriented and 
decision taking), Mintzberg (1973) studied behavior of leaders and drew the conclusion that 10 different roles could be played according to the situation. ${ }^{2}$ However, taking situational factors into consideration as an explanation of actual leadership resulted in quite some disillusions.

The fourth approach was initiated during the 1980's under the heading of the new leadership approach. Instead of focusing on situational circumstances, leaders have to be able to identify the mission of the firm and transform the organization accordingly. The transforming leader is capable of raising the aspirations of subordinates and to merge them with his/her own aspirations. Peters and Waterman's [In Search of Excellence (1982)] highly popularized this predominant position of the transforming leader, who as a charismatic actor has a passion for excellence and knows where he is going and can state it clearly and concisely (Peters and Austin 1986). Stories about heroic Chief Executive Officers (CEO's) were published and it was underlined that leaders are capable to communicate their vision, a process that entails depicting the status quo as unacceptable and generating a rhetoric, which aids the understanding of the vision (Conger 1989). Leaders with these qualities were being depicted as managers of meaning. As leaders, they have the capacity to lead others to lead themselves. Collins and Porras (1997) have illustrated how visionary companies develop training and promotion programs to ensure that their CEO's reflect the mission of the firm. Firms with truthful and authentic missions are called clock builders because they have a solid sourced internal mechanism to uphold their mission. In these organizations, there are no leaders of firms, but leaders within firms operating with teams.

Since the introduction of the New Leadership approach, a certain eclectic use of different perspectives on leadership has become a common feature. The difference between leadership and management has been obliterated although Zalenik (1977) had differentiated them clearly. Burton and Obel, for example, simply equate management with leadership and define a leader as the actor who "makes decisions, handles information, builds relationships with other people and motivates and controls subordinates" (Burton and Obel 1995: 96). One of the main qualities of these leaders/managers is the ability to deal with different values at the same time. "The art of leadership requires the simultaneous pursuit of several values" (O'Toole 1993: 7).

To prevent future studies from exploding into all kinds of directions and analyzing a pastiche of behaviors, however, Calori and de Woot (1994) have proposed to contrast the American, Japanese and European systems of management (at least) and to detect different leadership perspectives within these systems. These three systems are depicted below in Figure I.

Whitley (1999: 33), however, doubts whether a specific European management system is yet present. The single European market itself "has so far not resulted in standardized norms and rules governing

\footnotetext{
2 Interpersonal roles include those of the figurehead, leader and liaison:

- the informational category includes the roles of monitor, disseminator and spokesperson;

- the decisional category consists of the role of the entrepreneur, disturbance handler, resource allocator and negotiator.

The importance and intensity of each role varies with the level of the organisation, the type and the situation of the organisation.
} 
Figure I. Different Systems of Management

Characteristics of the US System of Management

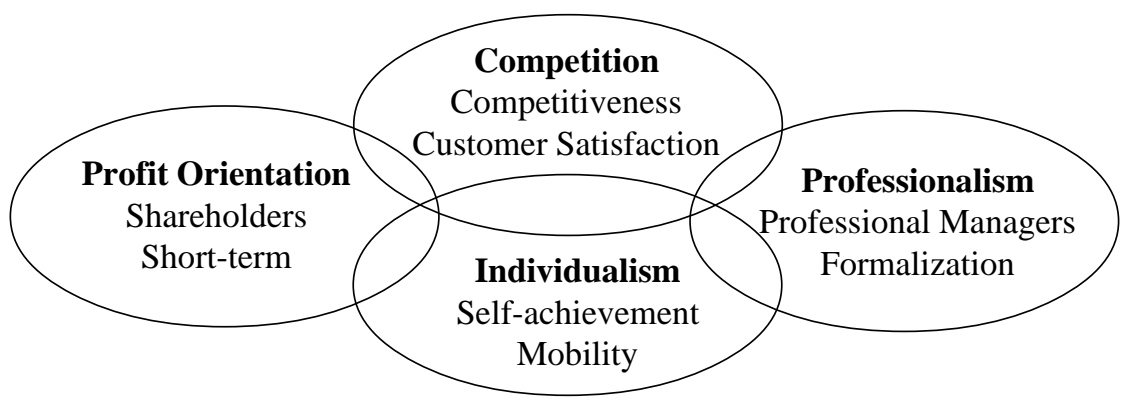

Characteristics of the Japanese System of Management

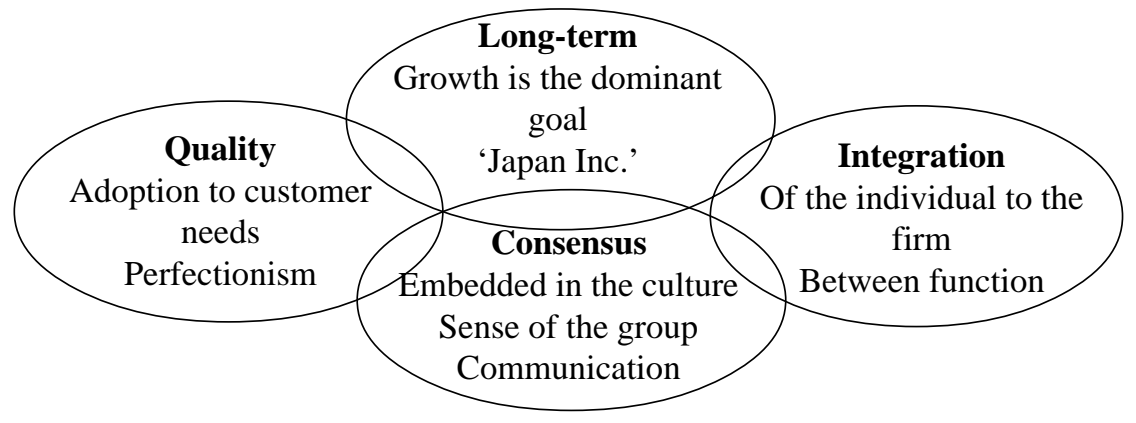

Ingredients of the European System of Management

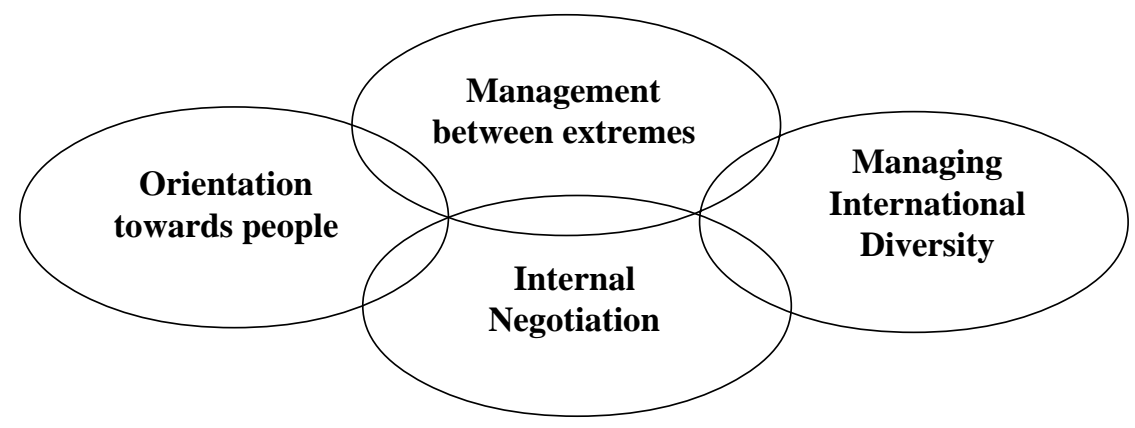


economic activities across Europe let alone the emergence of distinctly European firms which operate quite differently from national ones." Despite the existence of the European Economic Community, there is no clear identifiable European management style other than the recognition that the diversity amongst national institutional arrangements and national business systems have a strong influence on management practices within Europe (Lawrence and Edwards 2000).

Calori and de Woot's (1994) analysis offers an interesting perspective to question ourselves when a specific Asian, African or South American system of management will break through. Propositions in that direction will have to be studied critically. Sen (2000: 36) warns that sometimes "by selective citations of Confucius and by selective neglect of many other Asian authors, the view that Asian values emphasize discipline and order has been given apparent plausibility." He fears artificial distinctions, which will not be effective for the improvement of a reciprocal understanding. In order to reach the goal of reciprocal understanding, however, we will have to study how in the context of different systems of management, managers will develop a style that enables cooperation within and between different management systems. Otherwise companies operating in the global market will face serious problems based on misunderstanding and a lack of respect for cultural diversity.

\section{Management Styles}

Pascale and Athos published 'The Art of Japanese Management' in 1982, in which they used the famous $7 \mathrm{~S}$ model as it was jointly developed with Peters and Waterman (1982) of the McKinsey consultancy firm. They defined management style as "the characterization of how key managers behave in achieving the organization's goals. [.....] Style refers to the patterns of behavior of the top executive and the senior management team" (p. 81). Pascale and Athos (1982) did not described the essential pattern of behavior they had in mind, but their book illustrated how good managers have the capacity to properly communicate and establish a shared meaning. This indicates that management is above all a relational notion. The CEO of Motorola, Bob Galvin, for example, discarded the traditional concept of the CEO in favor of the concept of a Chief Executive Office, occupied by team members. He envisioned an office held by multiple team members (Collins and Porras 1997: 178).

Katzenbach and Smith (1993) envision the same by underlining the role of teams as groups of people with complementary skills who are committed to a common performance purpose, for which they hold themselves mutually accountable. Members of the team build commitment, confidence, remove barriers, create opportunities and are part of the team themselves. Even if there are individuals with leadership qualities within the teams, they only facilitate those who have the organizational skill to network and transmit a shared organizational culture. This transmission takes place through language, but language itself should not simply be perceived "as a simple means for the transportations of standardized meaning" (Alvesson 1996: 33). Instead, the purpose of a team of managers is to communicate their experiences, share their views and talk about them in order to create a shared meaning. Communicative action is a form of social interaction in which the plans of actions of the team members are coordi- 
GadjahMedaIntemational JamalofBusiness, January2002, Vol. 4, No. 1

nated through the use of language, and are oriented toward understanding and consensus building.

The focus is no longer on isolated managers. Instead the focus is on the social constitution of each individual manager through the relationships of mutual recognition into which he/she enters on the basis of his/her involvement in processes of communicative action. Team members, therefore, will have to adopt different attitudes toward the elements of three 'worlds' - the objective, the social and the subjective. According to the German philosopher, Habermas (1984, 1987), human beings relate to three different 'worlds' with three different attitudes:

- when they adopt an objective attitude, they relate to the objective world of facts and existing states of affairs;

- when they adopt a norm-confirmative attitude, they relate to the social world of normatively related interactions; and

- when they adopt an expressive attitude, they relate to the subjective world of inner experience.
These three attitudes are the fundamental sources to express propositional truth, normative rightness and subjective truthfulness. Habermas believes that with his pragmatic analysis of language as speech acts, we are able to distinguish three types of validity claims, which although distinct, interact in complex ways. For example, team members jointly have to agree on a meaning given to a specific state of affairs within the firm. Organizational change raises the question how to cope with it in normative terms and how to implement the agreed meaning into actions in expressive terms. The team members may have differences in opinion, but they will at least acknowledge the rightness of a particular choice, which has been made to realize an organizational change. To reach an agreement, team members use a language (game), in which the three validity claims will be dealt. With these validity claims, correspond three structural components of speech acts: the propositional, the illocutionary and the expressive.

Figure 2. Habermas Framework for a Pragmatic Speech Act Theory

\begin{tabular}{c|c|c|c|c} 
Words & Attitudes & $\begin{array}{c}\text { Validity } \\
\text { claim }\end{array}$ & $\begin{array}{c}\text { Structural } \\
\text { component } \\
\text { of speech acts }\end{array}$ & $\begin{array}{c}\text { Categories of } \\
\text { speech acts }\end{array}$ \\
\hline Objective & Objectivity & $\begin{array}{c}\text { Propositional } \\
\text { truth }\end{array}$ & Propositional & $\begin{array}{c}\text { Constative } \\
\text { (asserting) }\end{array}$ \\
Subjective & $\begin{array}{c}\text { Norm- } \\
\text { Conformative } \\
\text { Expressive }\end{array}$ & $\begin{array}{c}\text { Normative } \\
\text { rightfullness }\end{array}$ & Illuctionary & $\begin{array}{c}\text { Regulative } \\
\text { (promissing/ } \\
\text { requesting) }\end{array}$ \\
truthfullness & Expressive & $\begin{array}{c}\text { Expressive } \\
\text { (avowing) }\end{array}$
\end{tabular}


In addition, with the three validity claims, relate three categories of speech acts:

- constative speech acts, which raise a claim to propositional truth;

- regulative speech acts, which raise a claim to normative rightness. A speaker claims the right to say what he says to a hearer;

- expressive speech acts, which raise a claim to subjective truthfulness. The hearer can ask for example, 'what reasons do you have for expecting me to believe you mean that!" (Cooke 1994: $60)$.

Habermas' framework (see Figure 2) is useful to distinguish between a cognitive use of language, which focuses on the propositional content of an utterance and the interactive use of language (regulative speech acts), which focuses on the relationship that an utterance establishes between the speaker and the hearer. The cognitive use of language prevents a practical discourse about the meaning of cultural diversity within an organization. In this context, leaders are only perceived as the ones who engineer cultural values. With Habermas framework, we can focus on the interactive use of language. The communicative actions of a team have the purpose to reach an agreement with regard to all three validity claims and coordinate plans of actions to realize a specific goal.

This framework can effectively explain how specific management styles in firms are established. If a certain topic is raised within the team that has to do with normative or cultural aspects, regulative speech acts will prevail. Direct claims about normative rightfulness will then prevail and only indirect claims to truth and truthfulness will be expressed. In situations where many different value systems have to be integrated in an organizational culture, these regulative speech acts will dominate. Companies operating in the global market will have to promote a management style where persons with different cultural backgrounds are sensitive enough to understand each other's utterances in terms of normative rightfulness and subjective truthfulness, and not only in cognitive terms (Segalla et al. 2000). Managers have to assume the responsibility to listen carefully and to use their cognitive, normative and emotional imagination to grasp what is being expressed and said in traditions they might not be familiar with. They have to resist "the dual temptation of either facilely assimilating what others are saying to their own categories and language without doing justice to what is genuinely different [...] or simply dismissing what the "other" is saying as incoherent nonsense (Bernstein 1991: 66).

\section{Conclusion}

In the 1950s, Romein believed that the unification of the world would come about. As I have tried to highlight in this paper, it is not the unification of the world, but that of the global market, which is becoming a reality. Within that market system, it is not the invisible hand (Adam Smith) but the visible hand of management, which has obtained a dominant position. This visible hand has been portrayed as the hand of leaders, coordinating and controlling large-scale internationally organized firms with divisional subsidiaries or networked conglomerates. The New Leadership approach, however, has shown that leadership of firms is beginning to change into leadership within firms and within teams. Within those teams, leaders become invisible while their views become part of the vision of a team of executive managers who have established a com- 
GadjahMeda Intemational JoumalofBusiness, January2002, Vol. 4, No. 1

monly shared meaning. The creation of such a shared meaning is not the result of free floating individual managers, but is constituted by a specific system of management that reflects the society within which firms are operating. Today, organizations that operate in the global market are being confronted with an intensive cultural diversity. In order to be able to cope the problem, they will have to improve their communication manners.

Based upon the pragmatic analysis of language as developed by Habermas, we can understand how different management styles can be developed which include this diversity as an integral part of company practice and establish commonly shared meanings. Communicative rationality will make it possible to perceive and treat other people, other cultures, and other claims in an appropriate way. With communicative rationality, we can cultivate a 'moral imagination' (Sen 2000: 38) based upon principles of 'universal moral respect' and 'egalitarian reciprocity' (Benhabib 1992: 32). This is probably an appropriate translation of what Romein had in mind when he talked about the general human pattern of behavior, which will make it possible for participants in teams to fully take part in conversations, question any assertion, and introduce new topics and novel concepts. Communicative rationality will promote and visualize the development of management styles, which will demonstrate flexibility to deal with the volatility of the global market, integrate multicultural phenomena in the teambuilding of managers, and focus on the appropriate use of knowledge in language and action.

\section{References}

Albert, M. 1991. Capitalisme Contre Capitalisme. Paris: Seuil.

Alvesson, M. 1996. Communication, Power and Organization. Berlin: Walter de Gruyter.

Badham R.J. 1986. Theories of Industrial Society. London: Croom and Helm.

Bakthari, H. 1995. Cultural effects on management style: A comparative study of American and Middle Eastern management styles. International Studies of Management and Organization 25 (3).

Benhabib, S. 1992. Situating the Self. London: Routledge.

Bernstein, R.J. 1991. The New Constellation: The Ethical-Political Horizons of Modernity/Postmodernity. London: Polity Press.

Braithwaite, J., and P. Drahos. 2000. Global Business Regulations. Cambridge: Cambridge University Press.

Bryman, A. 1996. Leadership in organizations. In Clegg S.R. ea. Handbook of Organization Studies. London: Sage.

Burton, R.N., and B. Obel. 1995. Strategic Organizational Diagnosis and Design. Boston: Kluwer Academic Publishers. 
Karsten Management Styles in aGlobal Merket Econamy

Calori, R., and Woot de Ph. 1994. A European Management Model. New York: Prentice Hall.

Chandler, A.D. 1977. The Visible Hand. Cambridge: Harvard University Press.

Collins, J.C., and J.I. Porras. 1997. Built to Last. New York: Harper Business.

Conger, J.A., 1989. The Charismatic Leader: Behind the Mystique of Exceptional Leadership. San Francisco: Jossey-Bass.

Cooke, M. 1994. Language and Reason. Cambridge: MIT Press.

Frank, A.G. 1998. Re-orient: Global Economy in the Asian Age. London.

Habermas, J. 1984, 1987. The Theory of Communicative Action II. Beacon Press.

Hofstede, G. 1980. Culture's Consequences: International Differences in Work-Relational Values. London: Sage.

Hofstede, G. 1983. The cultural relativity of organizational practices and theories. Journal of International Business Studies (Fall).

Hollingworth, J.R., and R. Boyer. 1998. Contemporary Capitalism. Cambridge.

Israel, J.I. 1995. The Dutch Republic. Oxford: Clarendon Press.

Katzenbach, J.R., and D.K. Smith. 1993. The Wisdom of Teams; Creating the High Performance Organization. Boston: Harvard Business School.

Kerr, C. 1960. Industrialism and Industrial Man. Cambridge: Harvard University Press.

Lawrence, P.R.M., and J. Lorsch. 1967. Organization and Environment. Cambridge: Harvard University Press.

Lawrence, P., and V.Edwards. 2000. Management in Western Europe. London: McMillan Press.

McKenna, Ch.D. 1997. The American challenge: McKinsey company's role in the transfer of decentralization to Europe 1957-1975. Academy of Management Proceedings.

Maurice, M., F. Sellier, and J.J. Silvestre. 1982. Politique d'éducation et organisation industrielle en France et en Allemagne. Paris : Puff.

Maurice, M., and A. Sorge. 2000. Embedding Organizations. Amsterdam: John Benjamins publishing company.

Mintzberg. 1973. The Nature of Managerial Work. New York: Longman.

O'Toole, J. 1993. The Executive's Compass: Business and The Good Society. Oxford: Oxford University Press.

Parker, G. 1998. The Grand Strategy of Philip II. London: Yale University Press.

Pascale, R.T., and A.G. Athos. 1982. The Art of Japanese Management. Penguin Books.

Perrow, Ch. 1986. Complex Organizations. New York: Random House. 
GadjahMedaIntemational JamalofBusiness, January2002, Vol. 4, No. 1

Peters, T.J., and R.H. Waterman. 1982. In Search of Excellence. New York: Warner Books.

Peters, T.J., and H. Austin. 1986. A Passion for Excellence. London: Collins.

Pomeranz, K. 2000. The Great Divergence; Europe, China and the Making of The Modern World Economy. Princeton University Press.

Powell, W.W., and P.J. DiMaggio (eds.). 1991. The New Institutionalism Within Organizational Analysis. Chicago: University of Chicago Press.

Romein, J. 1952. In de Ban van Prambanan: Indonesische Voordrachten En Indrukken. Amsterdam: Querido.

Rothschild, E. 2001. Economic Sentiments: Adam Smith, Conclorect and the Enlightenment. Cambridge: Harvard University Press.

Schein, E.H. 1985. Organizational Culture and Leadership. San Francisco: Jossey-Bass.

Segalla, M., L. Fisher, and K. Sandner. 2000. Making cross-cultural research relevant to European corporate integration. European Management Journal 18 (1).

Sen, A. 2000. East and west: The reach of reason. New York Review of Books (20 July).

Smith, A. 1976. Wealth of Nations. Oxford: Clarendon Press.

Trompenaars, F., and C. Hampden-Turner. 1998. Riding the Waves of Culture. New York: McGraw-Hill.

Whitley, R. 1999. Divergent Capitalisms. New York: Oxford University Press.

Zaleznik, A. 1977. Managers and leaders: Are they different? Harvard Business Review (May-June). 